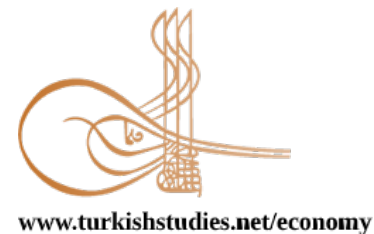

Turkish Studies - Economics, Finance, Politics

eISSN: 2667-5625

Research Article / Araştırma Makalesi

\title{
BDS-700 Finansal Raporlara İlişkin Görüş Oluşturma ve Raporlama Standardının BíST-50 Endeksi Kapsamındaki Firmalara Etkilerinin Değerlendirilmesi
}

\author{
Evaluation Of The Impact Of The BDS-700 Financial Reports On The Companies Under The BIST- \\ 50 Index And Reporting Standard
}

\author{
Tuba Derya Baskan*
}

\begin{abstract}
The aim of this study is to examine the Independent Audit Standard 700- Conceptualization and Reporting Standard in the Independent Audit Reports in a conceptual framework and to try to identify a number of factors affecting the opinions in the audit reports. Nowadays, public enterprises should present their financial reports within the framework of certain standards and with a certain reasonable confidence. For this reasonable trust, this opinions are given by independent audit institution reports are important. Independent audit standards-700 (BDS-700) The standard for forming opinions and reporting on financial reports was examined in the conceptual framework, and the steps to be taken when reporting the opinions of the auditors were specified. In order for the independent audit reports to be effective, the requirements were specified and the opinion types of the audit reports were examined. The types of positive, negative, conditional and unavoidable expressions in the independent audit reports were explained and the importance of these opinion types was discussed. For this purpose, the audit reports of the companies subject to the BIST 50 index between 2011-2018 were examined and variables that could affect the opinions in these reports were determined. According to the results reached, the fact that the audit firms are among the four big companies, the debt structures of the companies, their growth rates and net working capitals affect the audit opinions
\end{abstract}

Structured Abstract: The aim of this study is to examine the Independent Audit Standard 700Conceptualization and Reporting Standard in the Independent Audit Reports in a conceptual framework and to try to identify a number of factors affecting the opinions in the audit reports. Nowadays, public enterprises should present their financial reports within the framework of certain standards and with a certain reasonable confidence. For this reasonable trust, this opinions are given by independent audit institution reports are important. Independent audit standards-700 (BDS-700) The standard for forming opinions and reporting on financial reports was examined in the conceptual framework, and the steps to be taken when reporting the opinions of the auditors were specified. According to the BDS-700 standard, in order for the financial reports of the companies to be valid, an appropriate and understandable disclosure of the accounting policies, the compliance of the selected accounting policies with the financial reports, the correct accounting estimates, the information presented in the financial reports are appropriate, reliable, comparable and understandable,

\footnotetext{
* Dr. Öğr. Üyesi, Kırıkkale Üniversitesi, İktisadi ve İdari Bilimler Fakültesi, İşletme Bölümü Asst. Prof. Dr. Kirlkkale University, Faculty of Economics and Administrative Sciences, Department of Business ORCID 0000-0001-8809-7043

tdbaskan@gmail.com
}

Cite as/ Atıf: Başkan, T. D. (2020). BDS-700 finansal raporlara ilişkin görüş oluşturma ve raporlama standardının BİST-50 endeksi kapsamındaki firmalara etkilerinin değerlendirilmesi. Turkish Studies - Economy, 15(2), 781-797. https://dx.doi.org/10.29228/TurkishStudies.43194

Received/Geliș: 27 April/Nisan 2020

Accepted/Kabul: 20 June/Haziran 2020

Copyright (C INTAC LTD, Turkey 
the information users In order for financial reports to be used effectively, the titles in the financial reports used must be compatible with the terminology. At this stage, the most important thing required for the auditors is the evidence collected. Audit evidence should be sufficient to guide opinions in the auditor's reporting by determining whether financial reporting is prepared in accordance with accounting principles. With the collected evidence, the requirements of the audit reports were examined by specifying the requirements for the independent audit reports to be effective. The types of positive, negative, conditional and unavoidable expressions in the independent audit reports were explained and the importance of these opinion types was discussed. For this purpose, the audit reports of the companies subject to the BIST 50 index between 2011-2018 were examined and variables that could affect the opinions in these reports were determined. According to the results reached, the fact that the audit firms are among the four big companies, the debt structures of the companies, their growth rates and net working capitals affect the audit opinions. In this study, the independent audit report opinions are examined within the scope of BDS-700 and relations with a number of rates that may affect the audit opinions of firms in BIST 50 are tried to be determined by Simple Logistics Analysis method. According to the results; The fact that the audit firms are among the four major statistically audit opinion affects their reports. A one-unit increase in the size of the audit firm increases the opinion in the independent audit reports by 0.0754586 units. We can attribute this result to the fact that independent audit firms, which are well known and highly respected in the market, have a more transparent, open and trusting opinion in the reports; There is a statistically significant relationship between Firm Debt Rate and the opinion of independent audit reports. One-unit increase in firms' borrowing rate reduces the opinion in independent audit reports by -0.6904423 units. According to this result, the borrowing rate of the audited firms will increase according to their capital, while the audit will change their opinions. This can be said to be a factor in the negative decision of the audit firms as independent audit firms are affected by the economic conditions of the firms they audit in the market, and the decisions made by the creditors as a result of a wrong reporting may lead to crises; There is a statistically significant relationship between the growth rate of firms and the positive opinion of independent audit reports. One-unit increase in the growth rate of firms increases the opinion in the independent audit reports by 0.0237183 units. It is concluded that the fact that the firm that the independent auditors inspected is a growing company, that the reports are important and accordingly, the opinions of the companies that have increased their growth rates compared to the previous year have increased positively by the independent auditors. It can be said that for the independent audit firms, the economic situation of the firms they are auditing will lead to a positive change; There is a statistically significant relationship between the net working capital / Total Assets and the positive opinion of the independent audit reports. One-unit increase in the net working capital / Total Asset ratio increases the opinion in the independent audit reports by 0.3910892 units. As the liquidity ratio of the firms increases, it will change the independent audit reports as it shows the economic power of the firms. According to the results, the economic status of the audited firms and their rapid growth in the market affect the opinions of independent auditing firms. While the study is done in BIST-50, while the study is being created, the study can be extended by doing it on other samples and adding it to the model in other variables.

Keyword: BDS 700 Standard, Types of Audit Opinions, Ratio Analysis, BIST 50 Index, Simple Logistic Regression.

Jel Codes: M41, M42.

Öz: Bu çalışmanın amacı Bağımsız Denetim Standardı 700- Bağımsız Denetim Raporlarındaki Görüş Oluşturma ve Raporlama standardının kavramsal çerçevede incelenerek, denetim raporlarındaki görüşleri etkileyen birtakım faktörleri tespit etmeye çalışmaktır. Günümüzde halka açık işletmeler finansal raporlarını belli standartlar çerçevesinde ve belli bir makul güven vererek sunmalıdır. Bu makul güven için de bağımsız denetim kurum raporlarının verdiği görüşler de önem arzetmektedir. Bağımsız denetim standartları-700 (BDS-700) finansal raporlara ilişkin görüş oluşturma ve raporlama standardı kavramsal çerçevede incelenerek, denetçilerin görüşlerini raporlarken yapılması gereken aşamalar belirtilmiştir. Yine bağımsız denetim raporlarının etkin olabilmesi için gereklilikler belirtilerek denetim raporlarının görüş türleri incelenmiştir. Bağımsız denetim raporlarında yer alan olumlu, olumsuz, şartlı ve görüş bildirmekten kaçınma türleri açıklanarak bu görüş türlerin önemine değinilmiştir. Bu amaçtan hareketle, firmaların piyasa değeri ve işlem hacmi en yüksek olan şirketin BİST 50 endeksinde yer almasından kaynaklı 2011-2018 yılları arasındaki denetim raporlamaları incelenerek bu raporlardaki görüşleri etkileyebilecek değişkenler tespit edilmiştir. Kullanılan değişkenler literatür desteği ile denetim firma büyüklüğü, firma borç oranı, net kar, 
büyüme, firma büyüklüğü, Dönen Varlık/Kısa Vadeli Yabancı Kaynaklar, Net Çalışma Sermayesi/Toplam Aktifler ve Piyasa Değeri/Defter Değeri olarak belirlenmiştir. Ulaşılan sonuçlara göre denetim firmalarının dört büyükler arasında olması, işletmelerin borç yapıları, büyüme hızları ve net çalışma sermayeleri denetim görüşlerini etkilemektedir.

Anahtar Kelime: BDS 700 Standardı, Denetim Görüş Türleri, Oran Analiz Yöntemleri, Bist 50 Endeksi, Basit Lojistik Regresyon.

Jel Kodları: M41, M42.

\section{Giriş}

Bağımsız denetim kavramının en önemli amaçlarından biri bilgi kullanıcılar açısından güven ortamının yaratılmasıdır. İşletmelerin yönetim, pazarlama, dağıtım, ar-ge, muhasebe gibi bütün birimlerinin finansal raporlama süreçlerinden etkilendiği düşünülürse, bu sürece iyi odaklanmaları ve o doğrultuda çalışmalarını yapmaları gerekmektedir. Bu da ancak işletmelerde iyi bir kurumsallık sürecinin gelişmesi ile mümkün olabilmektedir (Ar1, 2008: 50-51). Birçok ülkede ortaya çıkan mali raporlamalar sonucu krizler ve şirket skandalları bu raporlamaların üzerinde yeni çalışmalar ve düzenlemelerin yapılmasını sağlamıştır. Firmaların finansal raporlamalarını, yatırımcılar, kredi verenler, işletme yöneticileri, çalışanlar ve devlet gibi bilgi kullanıcılarına doğru ve açıklayıcı bir şekilde sunmaları için piyasada meydana gelebilecek hileli raporlamaları önlemek amaciyla muhasebe ve denetim standartları oluşturulmuştur.

Dünyada hileli finansal raporlamalarından dolayı ilk krizlerin meydana geldiği ABD'de 1988 y1lında Amerikan Hile İnceleme Birliği (Association of Certified Fraud Examiners- ACFE) kurulmuştur. ACFE hileyi "kişi ya da kişilerin çalıştıkları ya da iliş̧i halinde bulundukları işletmelerin varlık ya da kaynaklarını, bilinçli olarak kendi çıkarları için değiştirerek yararlanılması" olarak tanımlamaktadır (ACFE, 2016). ACFE işletmelerde hile türlerini varlıkların kötüye kullanılması, hileli finansal raporlama ve yolsuzluk şeklinde sinıflandırmaktadır. Bu hile türlerini aşağıda açıklanmaktadır (ACFE, 2018).

Varlıkların kötüye kullanılması; daha çok küçük tutarlarda yapıldığı görülen hırsızlık, zimmet, amaç dışı kullanılan varlıklar,

Hileli finansal raporlama; bilgi kullanıcılarının yararlanacağı finansal raporları bilerek ve isteyerek rakamların değiştirilmesi, örneğin kar oranını yüksek göstermek, satışları fazla göstermesi,

Yolsuzluk; çalışanların firmadaki görevini kötüye kullanarak ahlak dışı davranışlar sergilemesi gibidir.

$\mathrm{Bu}$ hile türlerinde ACFE'nin yapmış olduğu 2018 hile raporlamaları tahminine baktığımızda (ACFE, 2016).

Yaklaşık \% 83 görülme varlıkların kötüye kullanılması (125.000 dolarlık kayıp)

Yaklaşık \%10 hileli finansal raporlama (975.000 dolarlık kayıp)

Yaklaşık \%37 yolsuzluk (850.000 dolarlık kayıp) olasılığı bulunmaktadır.

ACFE'nin sonuçları tahmini olsa da hileli finansal raporlamalar yapılması firmalara ciddi bir mali zarar vermektedir. Dolayısı ile bunun önüne geçebilmek için bağımsız denetim kurumlarına görevler düşmektedir. Bağımsız denetim denetlenen firmaların finansal raporlamaları hakkında doğruluğu ve güvenilirliliği artırmakta bu da, bilgi kullanıcılarının finansal tablolara olan güven derecesini yükseltmektedir. Bu kapsamda bağımsız denetçiler denetleyecekleri işletmelerin denetimin zamanını, raporlama planlamalarını, finansal işlemlerin denetiminin doğru olabilmesi için kalite kontrolünü, iç kontrol mekanizmalarının gözden geçirilmesini, mali raporlarlarının 
incelenmesinden elde edilen bilgilerin kanıtlara dayandırılarak raporlanmasını yapmakta ve görüş bildirmektedir (Pickett vd, 2005:10).

Bağımsız denetim raporları ile işletmelerin sürdürülebilirliğiyle ve gelecekteki gelişimi analiz edilmekte makul güvence vererek işletmeye olan güven artmaktadır. Özellikle meydana gelen muhasebe krizlerinden sonra kapsamı, sınırları ve sorumlulukları daha da netleşen bağımsız denetim kurumlarının, raporlarındaki görüşleri daha da önem kazanmıştır.

Bu çalışmanın amacı Bağımsız Denetim Standardı 700- Bağımsız Denetim Raporlarındaki Görüş Oluşturma ve Raporlama çerçevesinde BIST 50 endeksindeki firmaların denetim raporlarındaki görüşleri etkileyen bir takım faktörleri tespit etmeye çalışmaktır. Çalışmanın ilk kısmında ilgili standart kavramsal çerçevede incelenerek bağımsız denetim kurumlarının raporlamalarının etkinliğine bakılacaktır. Bağımsız denetim kurumlarının sunmaları gereken raporlama görüş türleri de anlatılacak ve literatür çalışması yapılacaktır. Literatür çalışmasında denetim rapor görüşlerini etkileyen faktörlerin neler olabileceği, ne şekilde ele alındığı ve hangi yöntemlerin kullanıldığından bahsedilecektir. Bunu takip eden süreçte ise BİST 50 endeksine tabi firmaların denetim raporlarını etkileyen faktörler Basit Logistik Analiz yöntemi ile ele alınacaktır.

\section{Bağımsız Denetim Standardı 700 - Bağımsız Denetim Raporlarındaki Görüş Oluşturma ve Raporlamanın Kavramsal Çerçevede İncelenmesi}

Ülkemizde 2005 yılından itibaren Sermaye Piyasası Kuruluna bağlı olan işletmelerin Finansal raporlarını Uluslararası Finansal Raporlama Standartları (UMS-UFRS)'na uygun düzenlemeleri zorunlu kılınmıştır. Bu kapsamda Resmi Gazete'de yayımlanan 6102 sayılı Türk Ticaret Kanunu ile 2011 yılında Kamu Gözetimi, Muhasebe ve Denetim Standartları Kurumu (KGK)'na muhasebe ve denetim alanında yetkiler devredilmiştir. KGK tarafindan yetki belgesi verilen kişi ve kurumların denetim faaliyetlerini Bağımsız Denetim Standartlarına göre gerçekleştirmesi gerekmektedir.

Türk Ticaret Kanunu (TTK) uyarınca bağımsız denetime tabi olacak işletmelerin belirlenmesine ilişkin Bakanlar Kurulu Kararı 23 Ocak 2013 tarihli Resmi Gazete'de yayımlanmış ve denetime tabi olacak firmalar için genel kriterler belirlenmiştir. TTK'ya göre denetimin konusu, mesleki etik ilkelerine bağlı kalarak, mesleki şüphecilik içinde bulunarak, Bağımsız Denetim Standartları (BDS) çerçevesinde kanıtların yeterli bir şekilde toplanması ve bu kanıtlar çerçevesinde bağımsız denetçilerin görüşünün raporlanmasını kapsamaktadır (TTK 6102, md.5). Türkiye'de 18.03.2014'de yayımlanan BDS-700 bağımsız denetim raporlarındaki görüş oluşturma ve raporlama biçimini incelemektedir. Bu standarda göre bağımsız denetim raporlarının görüş oluşturmak için belli başlı ilke ve kuralları bulunmalıdır.

İşletmelerin finansal raporlarının geçerli olabilmesi için (BDS 700, prg 13).

- Muhasebe politikalarının uygun ve anlaşı1ır şekilde açıklanması,

- Seçilen muhasebe politikalarının finansal raporlar ile uyumlu olması,

- Muhasebe tahminlerinin doğru şekilde yapılması, ve anlaşı1ır olması,

Finansal raporlarda sunulan bilgilerin ihtiyaca uygun, güvenilir, karşılaştııılabilir

- Bilgi kullanıcıların finansal raporların etkin kullanabilmesi için açık hazırlanması,

- Kullanılan finansal raporlardaki başlıkların terminoloji ile uyumlu olması gerekmektedir.

Denetçiler görüşlerini raporlarken başlık, muhatap, giriş paragrafı, yönetimin finansal tablolara ilişkin sorumluluğu, denetçinin sorumluluğu, denetçi görüşü, denetçinin imzası, denetçi raporu tarihi, denetçinin adresi başlıklarından oluşmaktadır. (BDS700, prg.21-42). Buna göre, 
İlk bölümde başlı̆̆1 yer verilmelidir. Yani "Bağımsız Denetçi Raporu” şeklinde başlık olmalıdır (BDS700, md.21)

Finansal raporlamaları denetlenen firma ve muhatapları, işletmenin ortakları/ hissedarlarına veya üst yönetimden sorumlu olanlara belirtilmeli, sonrasında raporların denetimden geçtiği belirtilmelidir (BDS 700, md.22). Raporlamalardaki her bir tablonun genel başlıkları belirtilir. Finansal raporların dönemi muhasebe politikaları ile ilgili özet de dâhil olmak üzere dipnotlara atıfta bulunularak hazırlanmalıdır (BDS-700, md.23-24).

Gerçek bilgilere uygun şekilde hazırlanması ya da uygunluk çerçevesinde hazırlanan finansal raporlamalara ilişkin olumlu görüş bildirilirken kabul edilen bazı ifadeler yer almaktadır ${ }^{1}$.

Denetçi görüşlerinde yer alan atıfların kaynağı yazılmalıdır.

Görüşün dayanağına göre, denetçilerin görüşlerinin, bağımsız denetçiler için etik kurallarına uygun olduğu, bağımsız denetim standartlarına uygun yürütüldügü, denetim kanıtlarının görüşlere ulaşmak için yeterli olup olmadığı belirtilmelidir. (BDS-700, prg.28).

Bağımsız denetime tabi olan firmalar işletmelerin finansal raporlamalarının denetimini kilit denetim konuları BDS-701'e uygun olduğunu bildirmelidir (BDS-700, prg.30).

Denetçilerin finansal raporlamalara ilişkin, yönetime ilişkin, bilgi kullanıcılara ilişkin sorumlulukları, "Yönetimin Finansal Tablolara İlişkin Sorumlulukları" başlığında belirtilmektedir. $\mathrm{Bu}$ başlıkta denetçilerin BDS'lerde belirtilen ilke ve kurallara göre uygun davrandığı, finansal raporlamaların hata ve hile içermediğine dair güvence verdiği, bu makul güvence için denetçinin BDS-701 Kilit Denetim konularına uygun olarak bildirdiği, yeteri kadar denetim kanıtlarının toplandığ 1 ifade edilmektedir. (BDS-700, prg 37-40).

Denetçinin ek birtakım sorumlulukları meydana geldiğinde, bunları ilave sorumluluklar olarak denetçinin denetim raporlamasında birtakım hususların ön plana alınması durumunda kendisinden raporlama yapılması talep edildiğinde ortaya çıkmaktadır (BDS-700, prg 41-43)

Denetçi raporunda, denetçilerin adı, imzası, adresinin olduğu (sorumlu denetçinin güvenlik sorunu olması dahilinde KGK'dan izin alarak yer vermeyebilir) ve raporun tarihi (tam set finansal raporlamaların hazırlanması için firma yönetiminin finansal raporlamalarla ilgili sorumluluklarının beyan edildiği tarihten önceki bir tarih olmamaktadır) belirtilmelidir (BDS-700, prg 46-47-49).

Denetçiler, mevzuata uygun bir şekilde denetim raporu düzenlemeleri için, bağımsız denetim standartlarına atıfta bulunmalıdırlar. Yine, başka bir denetim standardına uygun olarak yapılan denetçi raporlarının BDS'ler ile uyum sağlamış olması ve BDS'lere atıfta bulunulması gereken durumlar olabilir. Bunlar; başlık, sözleşmede öngörülen muhatap, etik kurallarına atıfda bulunma, finansal rapor başlıkları, sınırlı olumlu görüşün dayanağının BDS 570 ile uyumsuz olmayacak şekilde ele alınması gibi durumlar olabilmektedir (BDS 700- md50-51).

\section{Bağımsız Denetim Kurum Raporlamalarının Etkinliği}

Bağımsız denetim kurumlarının bağımsızlığı için bir takım kanuni düzenlemeler getirilmiş ve standartlar ile çerçevesi daha net bir şekilde belirlenmiştir. Buna göre denetim raporlamalarının kullanıcılar tarafından belli bir formatta rapor olarak hazırlanması gerekmektedir. Bu raporlama,

\footnotetext{
1(a) Görüşümüze göre, ilişikteki finansal tablolar [...'ları] [geçerli finansal raporlama çerçevesi]'ne uygun olarak tüm önemli yönleriyle gerçeğe uygun bir biçimde sunmaktadır veya

(b) Görüşümüze göre, ilişikteki finansal tablolar [...] [geçerli finansal raporlama çerçevesi]'ne uygun olarak doğru ve gerçeğe uygun bir görünüm sağlamaktadır.

- Uygunluk çerçevesi uyarınca hazırlanmış olan finansal tablolara ilişkin olumlu görüş verilirken, denetçi görüşü şu şekilde ifade edilir: "İlişikteki finansal tablolar, tüm önemli yönleriyle, [geçerli finansal raporlama çerçevesi]'ne uygun olarak hazırlanmıştır".
} 
firma yönetiminin faaliyetlerinin kapsamı, ekonomik sonuçları, firmanın hedeflerine ulaşıp ulaşmadığı, firmanın yönetim, pazarlama, ar-ge, muhasebe gibi bütün birimlerini ilgilendiren bir raporlama şeklinde olmalıdır (Örerler, 2005:2).

Finansal raporlamaların makul bir güvene ulaşabilmesi için ön yargıdan uzak bir raporlama süreci olmalıdır. Denetim sürecini Güredin (2014:67) müşteri seçimi ve işin alınması, denetimin planlaması, denetim programlarının yürütülmesi ve denetim bulgularının raporlanması şeklinde belirtmiştir. Denetim süreci uzman kişiler tarafından yapılması raporların denetim standartlarına uygun olarak hazırlanmasında ve yeterli kanıtların toplandığının belirtilmesinde etkin bir rol oynamaktadır. Bu da zaten bilgi kullanıcılara makul bir güven ortamı sağlamaktadır (Özsahin, 2000: 13-14).

$\mathrm{Bu}$ aşama da denetçiler için gerekli olan en önemli şey toplanan kanıtlardır. Denetim kanıtı, finansal raporlamaların muhasebe ilkelerine uygun hazırlanıp hazırlanmadığını tespit ederek denetçi raporlamalarındaki görüşlere yön verecek sayıda yeterli olması gerekmektedir. Denetçiler denetim kanıtlarını toparlarken, denetçilerin mesleki tecrübeleri ile yatırımcıların karar vermelerinde önemli düzeyde etkin rol oynamasına göre karar vermeye, raporlamalarda yapılacak hata ve hile riskini azaltmaya, kanıtları toplarken ekonomik etkenleri göz önüne alarak maliyeti çok artırmamaya ve kanıtların türü ve güvenilirliğinin de yeterli olmasına dikkat etmelidirler (Gönen ve Yildırım, 2019:1089-1090).

Toplanan kanıtların belirlenmesinden sonra denetçi raporlarında "Kilit Denetim Konuları (KDK)" başlığı altında bir açıklama yapılmalıdır. Standartta göre bildirilecek KDK sayısı belirtilmemekte iken borsa da işlem gören şirketlerin en az bir tane KDK belirlemesi gerekmektedir. Denetim raporlamaların da görüş bildirmeden önce KDK'ya ilişkin açıklamalar yapılması, ne kadar ayrıntılı bilgiye yer verileceği, işletmeye özgü bilgilerin yer verilmesi, standartlaştırılış denetim raporlarından uzaklaşmayı, firmaların finansal raporlamaları hakkında, daha uygun bir görüşün bildirilmesini sağlamaktadır (Doğan, 2018:78-79).

Sonuç da bağımsız denetim raporlarının etkinliğinin artması için, denetim raporlamalarının belli başlı standartta göre hazırlanan raporlardan uzaklaşması ve oldukça yalın hazırlanan raporlamaların kapsamının firma özellikleri göz önüne alınarak genişletilmesi gerekmektedir. Firmaların sürekliliği ile ilgili belirsizlik varsa kilit denetim konuları, yönetimin finansal raporlamalara karşı sorumluluğu, bağımsız denetçinin sorumluluğu, uyulması gereken mevzuata ilişkin hükümler göz önüne alınarak raporlamalar yapılmalıdır.

\section{Bağımsız Denetim Kurumlarının Sundukları Görüş Türleri}

3568 sayılı Serbest Muhasebeci Mali Müşavirlik ve Yeminli Mali Müşavirlik Kanununa göre; denetçi olabilmek ve bağımsız denetim yapabilmek için bazı şartlar belirtilmiştir. Denetim sadece Kamu Gözetimi Muhasebe ve Denetim Standartları Kurumu (KGK) tarafindan yetkilendirilen denetim kuruluşları ve denetçiler tarafından yapılmaktadır (TTK Md.400).

Bağımsız denetçilerin raporlamaların da çeşitli görüş bildire bilmektedir.

1. Olumlu görüş yazısı

2. Sinırlı olumlu görüş yazısı

3. Olumsuz görüş yazısı

4. Görüş bildirmekten kaçınma

TTK'da yer alan denetim raporlarının türleri KGK'nın yayınladığı Türk Denetim Standartları'nda (TDS) ve SPK'nın Seri X 22 numaralı tebliğinde yer almaktadır. Bu standartlarda ve tebliğde denetim raporlarının şekil şartları da yer almaktadır. Buna göre denetim raporlarında bulunması gereken şekil şartları şunlardır (BDS-700, prg. 21-42). 
Kamu Gözetimi Kurumu 01.01.2013 tarihinde ve sonrasında uygulanması için BDS-700 ve BDS- 705'e göre finansal raporlamalar için görüş bildirme standartlarını yayınlamışlardır. Buna göre;

Finansal raporlamaların tüm yönleri ile ilke ve kurallara uygun şekilde hazırlanması durumunda denetçiler olumlu görüş vermektedirler (BDS-700). Türk Ticaret Kanunu 398.md'ye göre denetçiler olumlu görüș verdiklerinde, öncelikle Türk Muhasebe Standartlarına göre denetimin yapıldığını, bu standartlar gereği herhangi bir sorun olmadığını, firma denetimi sırasında finansal raporların doğru olduğunu, kârlılığın doğru tespit edildiğini ve gerçeğe uygun bulunduğunu belirtirler. (TTK, Md 398).

Denetçiler BDS-705'e göre olumlu görüşün dışında, sınırlı olumlu görüş (şartlı görüş), olumsuz görüş ve görüş vermekten kaçınma şeklinde görüşlerini bildire bilmektedirler. Söz konusu standarda göre, denetçiler, denetim kanıtlarına dayandırarak söz konusu finansal raporlamaların yanlış bir sonuç verdiklerini tespit ederlerse ve bu yanlışlıkların önemli olduğunu belirtirlerse olumsuz görüş sunabilmektedirler. Diğer taraftan denetçiler finansal raporlamalarda tam olarak tespit edilemeyen ama etkilerinin önemli olabileceğini belirten bir yanlışlık tespit etmişlerse sınırlı olumlu görüş verebilirler. Yine denetim kanıtlarını yeterli ve uygun bir şekilde elde edemezlerse ve finansal raporlamalar üzerinde herhangi bir görüş oluşturmanın mümkün olamadığını tespit ederlerse de bir görüş sunmayabilirler (BDS-705 ve Yaşar, 2015:84).

Aşağıdaki Tablo 1 de denetim raporlamaları sonucu elde edilen verilerin önemlilik düzeylerinin ve bilgi kullanıcıların karar vermede kullanacakları görüşün önemini Güredin (2014)'de şu şekilde göstermiştir.

Tablo 1: Görüș Oluşturmada Önemlilik

\begin{tabular}{|c|c|c|}
\hline Önemlilik Düzeyi & Kullanıcı Kararlarına Etki & Görüş Türü \\
\hline Tutarlar önemsizdir & Kullanıcıların kararları etkilenmez & Olumlu \\
\hline $\begin{array}{l}\text { Tutarlar önemlidir; } \\
\text { Finansal tablolar bir bütün olarak } \\
\text { doğru ve güvenilirdir }\end{array}$ & $\begin{array}{l}\text { Hata ve yanlışlıklar kullanıcıların } \\
\text { kararlarını etkilemektedir. } \\
\text { Fakat finansal raporların dürüst } \\
\text { olmasına gölge düşmemiştir. }\end{array}$ & Şartlı \\
\hline $\begin{array}{l}\text { Tutarlar yeterince önemlidir; } \\
\text { finansal tablolar bir bütün olarak } \\
\text { doğru ve güvenilir değildir. }\end{array}$ & $\begin{array}{l}\text { Finansal tablolara dayalı olarak } \\
\text { karar alan kullanıcıların tümü, ya } \\
\text { da çoğunluğu önemli derecede } \\
\text { etkilenmektedir. }\end{array}$ & $\begin{array}{l}\text { Görüş bildirmekten kaçınma veya } \\
\text { olumsuz görüş }\end{array}$ \\
\hline
\end{tabular}

\begin{tabular}{l|l}
\hline Denetçi bağımsız değildir. & Görüş bildirmekten kaçınma
\end{tabular}

Buna göre, kullanıcı kararlarını etkileyen ve finansal raporların doğru ve güvenilir olmasını sağlayan bilgilere göre önemlilik düzeyi ve görüş türleri değişmektedir. Çünkü denetim, firmaların finansal tablolarının güvenilirliliğini artırmakta, yönetim ve çalışanlar tarafından yapılan hata ve hileleri ortaya çıkarmakta, kredibilirliliklerini artırmakta, işletmelerin finansal performansını değerlendirmekte, müşterilere ve tedarikçilere finansal durum hakkında bilgi sağlamaktadır (Gönen ve Yıldırım, 2019: 1088).

Yukarıdaki tabloda görüldüğü üzere, bağımsız denetim faaliyetleri bilgi kullanıcılara makul bir güvence sağlamakta ve alacakları kararlarda etkin bir rol almaktadır. Finansal tablo kullanıcıları açısından karmaşık muhasebe süreci sonrasında elde edilen finansal raporların güvenilirliğini ve doğruluğunu test etmek mümkün olmamaktadır. bilgi kullanıcılar denilen, yatırımcılar, kredi kuruluşları, çalışanlar, ortaklar, devlet gibi kullanıcıların verecekleri kararlardan zarar görmemesi açısından bağımsız denetim faaliyetlerine ihtiyaç duyulmaktadır. Bu aşamada da denetçinin 
finansal bilgi kullanıcılarına makul bir güvence sunabilmesi için yeterli ve uygun miktarda denetim kanıtı elde etmesi zorunludur. Çalışmanın ilerleyen kısmında ülkemizde geçerliliği kabul alan BDS-700 standardı çerçevesinde yapılan bağımsız denetim görüşleri ile ilgili yapılan literatür çalışmalarına bakılacaktır.

\section{Literatür Çalışmaları}

BDS-700 standardı 2013 y1lında ülkemizde yürürlüğe girmesinden kaynaklı ilgili y1ldan itibaren uygulanan BDS 700 standardı kapsamında çalışmalara bakılmıştır.

Ülkemizde 2003-2009 döneminde işlem gören sınai firmalar için parametrik olmayan Kikare bağımsızlık testi kullanılarak, olumsuz denetim görüşü ve bağımsız denetçi değişikliği arasındaki ilişkiyi tespit etmeye çalışan Yaşar (2015), olumsuz denetim görüşü ve bağımsız denetçi değişikliği arasında anlamlı bir ilişki olduğunu tespit etmiştir. Bunu da olumsuz görüş olduğunda firmaların denetçi revizyonuna gitmelerine bağlamışlardır. Yine incelemede olumsuz görüş sonrası denetçi değiştiren firmaların, izleyen yılda olumlu denetim görüşü almalarının da zor olduğunu belirtmişlerdir.

6102 sayı1ı Türk Ticaret Kanunu'na (TTK) ve bağımsız denetim standartlarına göre denetçi tarafından düzenlenecek olan görüş yazısı türleri ve bu yazıların şirket yönetimine olası etkilerini inceleyen çalışmayı Altaş $(2016,153)$ 'da yapmıştır. Çalışma da denetçi görüşlerinin nasıl şekillendiği, görüş bildirirken hangi aşamalara dikat edilmesi gerektiği, toplanması gereken kanıtların neler olduğu, her bir görüşün şartlarının nasıl olması gerektiğini inceleyen bir çalışmadır.

Akdoğan vd (2016), 2014-2016 y1lları arasında Borsa İstanbul firmaları ile ilgili denetim görüşlerini incelemişlerdir. Toplamda 511 firmanın denetim raporlarını inceleyerek, BDS-570 "İşletmenin Sürekliliği” ve BDS-700 "Finansal Tablolara İlişkin Görüş Oluşturma ve Raporlama" standartları ile denetim raporların birtakım istisnalar dışında uyum içinde hazırlandığı tespit edilmiştir. Kötüleşen ekonomik koşulların, işletmelerin sürekliliğinden ve KGK'nın denetim firmaları üzerinde artan denetim etkilerinden kaynaklandığı belirtilmiştir. Yine alacakların tahsilatı ile ilgili belirsizlik ve sorunlar, ortalık ve ilişkili taraftlarla olan işlemlerin belirsizliği, son zamanlara göre artan olumlu görüş dışında görüş verme raporlarının arttığı ama yine de en fazla olumlu görüş verildiği çalışmanın tespitlerindendir.

2011-2015 Borsa İstabul'da Yaşar (2017) işlem göre sınai işletmelerinde, basit lojistik regresyon analizi ile denetim görüşlerini ele alan bir çalışma yapmıştır. Önceki denetim görüşleri ve denetim rapor gecikmesi değişkenlerini, işletmenin sürekliliğine ilişkin belirsizlik içeren görüş türlerine göre anlamlı bulmuştur.

BDS-700 kapsamında bağımsız denetim raporunda denetçilerin standarttan kaynaklı yükümlülükleri detaylı olarak Aydın ve Çürük $(2017,238)$ tarafından literatüre dayalı olarak incelenmiştir. Denetim raporlarının TTK ve BDS kapsamında değerlendirilerek, makul güvence seviyesine ulaşabilmek için denetim riskinin en düşük düzeyde düşürülerek ulaşıldığını vurgulamışlardır. Yanık ve Karataş (2017) BDS-700 ve BDS 701 kapsamında denetçi raporlarındaki yenilikleri ve kilit denetim konularını açıklamakta, ülke uygulamalarına yer verilmekte ve eski ile yeni denetim raporlarının farkı ve bezerlikleri ortaya konmaktadır. Çalışma da yeni denetim raporları ile denetim sürecin ve kapsamının daha açık bir şekilde anlaşılması, denetçinin daha iyi ilişki kurması, denetçilerin önemlilik kavramını daha iyi anlayarak standart raporlamalardan uzaklaşılıp firma itibari ile denetçi raporlarının farklılaşması beklenen sonuçlar arasında olduğu vurgulanmıştır.

Bağımsız denetimde uygulanan Sermaye Piyasası Kurulu (SPK) tarafindan yayınlanan Denetim Standartlarından, Kamu Gözetimi, Muhasebe ve Denetim Standartları Kurumu (KGK) tarafından yayınlanan Türkiye Denetim Standartları'na (TDS) geçiş yılı olan 2013 ve 2014 yılında Borsa İstanbul'da işlem gören firmaların denetim raporları ve bu raporlarda yer alan denetim 
görüşlerini inceleyen Sekizsu ve Ertaş (2018), denetim raporlarının SPK Denetim Standartları ve Türkiye Denetim Standartları tebliğlerine uygunluk dereceleri ile denetim görüşleri ve uygulanan standart setlerinin, denetim firmaları ile aralarında bir ilişki olup olmadığını araştırmışlardır. Ulaşılan sonuçlara göre, 2013 yılında denetim görüşleri, denetim firmalarına göre farklılaşmakta, denetimde kullanılan standart setine göre farklılaşmamaktadır. Buna karşılık standart seti denetim şirketlerine göre farklılaşmaktadır. 2014 yılında ise denetim görüşleri, denetim şirketlerine ve standart setine göre, standart seti de denetim şirketlerine göre farklılaşmaktadır.

Mat ve Önal (2019) bağımsız denetim raporlarında denetim görüşünü etkileyen faktörleri, imalat sektöründe 2013-2017 yılları arasında firmalara ait finansal ve finansal olmayan veriler ile analiz etmişlerdir. Denetim raporlarındaki görüşün, finansal ve finansal olmayan değişkenlerden etkilendiğini tespit etmişlerdir. Sürekliliğe ilişkin belirsizlik içeren olumlu görüş dışında denetim görüşü ve sürekliliğe ilişkin belirsizlik içermeyen olumlu görüş dışında denetim görüşünü etkileyen faktörlerin kısmen farklılaştığını belirtmişlerdir.

\section{Araştırma ve Yöntem}

Çalışmanın bu bölümünde modele konulan değișkenlerin çeșitleri, örneklem modelinin seçilme amacı, araştırma yönteminin türü ve denetim raporlarındaki görüş çeşitlerinin etkilendiği faktörlere yer verilecektir.

\section{1. Örneklem Seçimi ve Değișkenlerin Belirlenmesi}

$\mathrm{Bu}$ çalışma Borsa İstanbul- 50 (BİST-50)'de işlem gören firmaların 2011-2018 yılları arasındaki denetim görüşlerini incelenmiştir. BİST-50'deki firmaların incelenmesinin sebebi BİST100 de yer alan firmaların piyasa değeri ve işlem hacmi en yüksek olan 50 şirketin yer almasıdır. 2011-2018 yılları arasındaki denetim görüşleri çalışmanın bağımlı değişkenini oluşturmaktadır. Çalışmanın denetim raporları her bir firmanın faaliyet raporları indirilerek tespit edilmiştir. Bağımsız değişkenlere ise firmaların Kamuoyu Aydınlatma Platformu (KAP) web sayfasından yararlanılarak ulaşılmıştır. 2011-2018 yılları arasındaki tam veri setinde BISST-50'de yer alan 40 adet firma için tam olarak ulaşılmıștır. Ulaşılamayan ve eksik veriler ile modelimiz çalıştırılamadığından 10 adet firma model dışı bırakılmıştır. Toplam 40 adet firmanın sekiz yıllık verileri ile ulaşılan toplam görüş sayımız 320 adettir. Bu görüşlerden 43 adeti olumsuz görüş, sınırlı olumlu görüş yazısı ve görüş bildirmekten kaçınma görüşlerine sahiptir. Geri kalan bağımsız denetim raporu ise olumlu görüş içermektedir. Bu kapsamda bağımlı değişkenimize olumlu görüş için "1", diğerleri için ise " 0 " verilmiştir.

Çalışmada kullanılan bağımsız değişkenler, literatürde bağımsız denetim raporlarını etkilemede temsil ettiği düşünülen değişkenler referans alınarak belirlenmiştir. Bu değişkenler aşağıdaki Tablo 2'de gösterilmiştir.

Tablo 2: Modele Dahil Edilen Bağımlı ve Bağımsız Değişkenler

\begin{tabular}{l|l|l}
\hline Değişken Adı & Kısaltmalar & Hesaplanması \\
\hline $\begin{array}{l}\text { Görüş Bildirme } \\
\text { bağımlı değişken) }\end{array}$ & $\mathrm{g}$ & $\begin{array}{l}\text { Olumlu Görüs “1” } \\
\text { Diğerleri “0” }\end{array}$ \\
\hline Denetim Firma Büyüklüğü & $\mathrm{dfb}$ & Dört Büyükler “1”, Diğerleri “0” \\
\hline Bağımsız Denetim Standartları & bds & $\begin{array}{l}\text { Bds Kullanan “1”, Kullanmayan } \\
\text { "0" }\end{array}$ \\
\hline Firma Borç Oranı & kalo & Toplam Borç/Toplam Varlık \\
\hline Net Kâr & lnnk & Net Kâr Logaritması \\
\hline
\end{tabular}




\begin{tabular}{l|l|l}
\hline \hline Büyüme & bh & $\begin{array}{l}\text { Toplam Aktiflerdeki Yıllık } \\
\text { Değişim }\end{array}$ \\
\hline Firma Büyüklüğü & lnta & Toplam Varlıkların Logaritması \\
\hline $\begin{array}{l}\text { Dönen Varlık/Kısa Vadeli } \\
\text { Yabancı Kaynaklar }\end{array}$ & dvkvk & $\begin{array}{l}\text { Dönen Varlık/Kısa Vadeli } \\
\text { Yabancı Kaynak }\end{array}$ \\
\hline $\begin{array}{l}\text { Net Çalışma Sermayesi/Toplam } \\
\text { Aktifler }\end{array}$ & ncsta & $\begin{array}{l}\text { Net Çalışma Sermayesi/Toplam } \\
\text { Aktif }\end{array}$ \\
\hline Piyasa Değeri/Defter Değeri & ppdd & Piyasa Değeri/Defter Değeri \\
\hline
\end{tabular}

Tablo 2'de görülen bağımsız değişkenleri incelersek;

Denetim firma büyüklüğü; Denetim firmaların dört büyükleri olarak belirlenen ve Türkiye de bu denetim firmalarını temsil eden denetim firmaları aşağıdaki gibi belirlenmiştir (Sekizsu ve Ertaş, 2018, 45).

PWC (Başaran Nas Bağımsız Denetim ve YMM A.Ş.),

Deloitte Touche Tohmatsu (DRT Bağımsız Denetim ve YMM A.Ş.),

Ernst\&Young (Güney Bağımsız Denetim ve YMM A.Ş.)

KPMG International (Akis Bağımsız Denetim ve YMM A.Ş.).

Çalışma da denetim görüşünü etkileyen faktörlerden biri olarak kabul edilen denetim firmalarının büyüklüğüdür. Literatürde bağımsız denetim firmalarının büyüklüğünün denetim raporlarına güveni artırdığı tespit edilmiştir (Ireland, 2003: 987 \&DeAgelo,1981: 191). Çalışma da dört büyükler tarafından denetimi yapılmışsa "1" aksi durumda " 0 ” verilmiştir.

Bağımsız Denetim Standartları -700; Bu standardın geçerliliği, 01.01.2013 tarihinden sonra Bakanlar Kurulu kararı ile firmalar tarafindan uygulanmak üzere 18.03.2014 tarihinde 289545 sayılı resmi gazetede yayınlanmıştır. BDS-700 standardının paragraf 10-11-14 ve 15 . Maddelerine göre, makul bir güvence elde etmek için hazırlanan raporlamaların tüm yönleri ile geçerli hazırlanması, gerçeğe uygun hazırlanması ve finansal tablolarda yeterince atıfta bulunulması gerekmektedir. Gerçekleştirilen denetim raporlarının tüm ilke ve şartlara uygun olarak hazırlanması durumunda olumlu görüş verilmekte aksi durumda olumlu görüş dışındaki görüşlerin tercih edilmesi gerekmektedir (BDS-700, prg 25-26-30).

Çalışma da bu şartlar göz önüne alınarak BDS-700 kapsamında denetim raporları değerlendirilmiş ise " 1 " aksi duruma " 0 " verilmiştir.

Firma Borç Oranı; Firmaların ne kadarlık kısmının borç ne kadarlık kısımının öz kaynak ile finanse edildiği önemli bir unsurdur. Denetim görüşleri ile firma borç oranı arasındaki yapılan literatür çalışmalarına bakıldığında, bu oran yükseldiği sürece firmalara olumlu görüş vermenin azaldığı belirlenmiştir. Borçlanma oranı toplam borç/toplam varlık ile ölçülmüş ve literatürde de bu oran ile yapılan çalışmalar bulunmuştur (Ireland 2003 \&Yaşar ve diğerleri 2015 \& Yaşar 2016 \&Özcan 2016\&Habib 2018).

Net Kâr; Literatür de kârlılık ile denetim raporlarının görüşlerini inceleyen bir çok çalışma yapılmıştır. Çalışmalardan bazıları kârlılığı direk net kâr olarak alırken bazıları da net kâr/özkaynak ya da net kâr /toplam varlık oranlarını kullanarak ele almışlardır. Amaç kârlılığın denetim raporlarının görüşlerini nasıl etkilediğini tespit etmek ile olumlu ve olumsuz görüşler belirlemektir (Habib 2013, Özcan 2016, Yaşar vd 2015, Ireland 2003, Chen vd 2001, Mat ve Önal, 2019). Çalışma da firma net kârın doğal logaritması alınarak modele sunulmuştur. 
Büyüme; Firma büyümesi toplam aktifteki yıllık değişim oranı ele alınarak hesaplanmıştır. Denetim firmalarının görüşleri ile firma büyüme oranı arasında ilişkiyi inceleyen çalışmalar yapılmıştır (Mat ve Önal 2019 \& Özcan: 2016).

Firma Büyüklüğü; Bağımsız denetim raporlarının görüşünü etkileyen bir diğer faktör olarak literatürde firma büyüklüğünün incelendiği tespit edilmiştir. Firma büyüklüğü şirketlerin toplam varlıklarının doğal logaritması alınarak tespit edilmiştir (Habib 2013 \& Ireland 2003 \&Mat ve Önal 2019 \&Yaşar: 2016).

Likidite; Firmaların likiditesi genel de literatürde iki şekilde tespit edilmiştir. Birinci likidite oranı, dönen varlıklar/ kısa vadeli borçlar (dvkvk) iken ikinci likidite oranı net işletme sermayesi/toplam varlıklar (ncsta) değişkenleri olarak ölçülmüştür. Yüksek likidite ve düşük likiditeye göre bağımsız denetim raporlarının görüşlerinde farklılık olduğunu belirten çalışmalar literatürde yapılmıştır. (Caramanis ve Spathis 2006 \& Yaşar 2016 Yaşar 2017 \&Mat ve Önal 2019).

Piyasa Değeri; Piyasa değerinin defter değerine oranlanması ile bulunulan değerdir (pp/dd). Piyasa değeri, firmaların borsada işlem gören hisse senetlerinin fiyatlarına göre değişen tutardır. Defter değeri ise firmaların varlıkları ile borçları arasındaki fark yani firmaların sahip olduğu öz sermayedir. Piyasa değeri ile defter değeri oranlaması ise yatırımcıların çok fazla göz önüne aldığı oranlar arasındadır. Firmaların piyasa değerinin bilançolarındaki defter değerinin üstünde ya da altında olmasına göre diğer firmalar ile karşılaştırma yapmayı sağlayan bir orandır (Asalnoğlu vd, 2016:19). Bu oranın denetim görüşlerini nasıl etkilediği çalışmamızda ele alınmıştır. Literatürde denetim görüşleri ile bu oran arasında direk bir çalışmaya rastlanılamazken, bu oranı da dahil etmek yatırımcılar açısından önemli olduğu düşünülmektedir.

Değişkenler belirlendikten sonra hipotezlerimiz Tablo 3 de şu şekilde oluşturulmuştur.

Tablo 3: Araştırma Hipotezleri

Hipotez 1: Denetim firma büyüklüğü ile bağımsız denetim raporlarının görüşü arasında istatistiksel açıdan anlamlı bir ilişki vardır.

Hipotez 2: Bağımsız Denetim Standartları-700 ile bağımsız denetim raporlarının görüşü arasında istatistiksel açıdan anlamlı bir ilişki vardır.

Hipotez 3: Firma Borç Oranı ile bağımsız denetim raporlarının görüşü arasında istatistiksel açıdan anlamlı bir ilișki vardır.

Hipotez 4: Net kâr ile bağımsız denetim raporlarının görüşü arasında istatistiksel açıdan anlamlı bir ilişki vardır.

Hipotez 5: Büyüme hızı ile bağımsız denetim raporlarının görüşü arasında istatistiksel açıdan anlamlı bir ilişki vardır.

Hipotez 6: Denetlenen firma büyüklüğü ile bağımsız denetim raporlarının görüşü arasında istatistiksel açıdan anlamlı bir ilişki vardır.

Hipotez 7: Dönen varlıklar/ kısa vadeli borçlar (dvkvk) ile bağımsız denetim raporlarının görüşü arasında istatistiksel açıdan anlamlı bir iliş̧i vardır.

Hipotez 8: Net işletme sermayesi/Toplam varlıklar (ncsta) ile bağımsız denetim raporlarının görüşü arasında istatistiksel açıdan anlamlı bir ilişki vardır.

Hipotez 9: Piyasa Değeri/Defter değeri ile bağımsız denetim raporlarının görüşü arasında istatistiksel açıdan anlamlı bir ilişki vardır.

Araştırma değişkenleri ve hipotezler belirlendikten sonra modelimizi analiz edebilmek için bağımlı değişkenin sonucunun ikili gruba ayrıldığında uygulanan "Basit Lojistik Regresyon" analizi yapılacaktır.

\section{Analiz ve Yöntem}

Basit lojistik yöntem, probit modele alternatif oluşturan ileri düzey bir regresyon yöntemidir. Lojistik analiz yönteminin temel amacı, bağımlı değişkenimiz ile birden çok bağımsız 
değişkenimiz arasındaki ilişkiyi oluşturmaktır (Ege ve Bayraktaroğlu, 2019:146). İleri bir istatistik olan yöntem lojistik regresyon yönteminde, bağımlı değişkenimizin sonucu en az ikili olmak üzere " 0 " ve " 1 " şeklinde gruplara ayrılmakta ve bu durumda basit lojistik yöntem kullanılmaktadır. Bağımlı değişkenimiz " 0 ", "1", "2" ve "3" gibi ikiden daha fazla gruplara ayrılmakta ve bu durumda çoklu lojistik regresyon yöntemi kullanılmaktadır. Yani bağımlı değişkenimizi gruplara ayırarak kullandığımız bir regresyon yöntemdir (Akgül ve Çevik, 2005:390). Lojistik regresyon yönteminin matematiksel olarak sonuçlarının esnek olması ve yorumlanmasının kolay olması bu yöntemin tercih edilme sebeplerindendir. Ayrıca modelin temeli olasılık oranına dayanmakta olduğu için, bir olayın gerçekleşme olasılığı ile gerçekleşmeme olasılığını karşılaştırdığg için de tercih sebeplerinden sayılmaktadır.

Bağımlı değişkenimiz " 0 " ve "1" değeri almasından dolayı uygulayacağımız basit lojistik regresyon analizi ile bağımlı değişken ile bağımsız değişken arasındaki ilişkiyi açıklamaktadır. Lojistik regresyon modeli aşağıdaki gibi tanımlanmaktadır (Ural vd.2015: 90).

$$
\operatorname{loglt}(\mathrm{p})=\log \frac{p}{1-p}=\mathrm{X}^{1} \beta+v
$$

$\mathrm{p}=$ olumlu görüş,

$1-p=$ olumsuz görüş,

$v=$ hata terimi

$\mathrm{X}^{1}=$ Bağımsız değişkenleri

$\beta=$ regresyon katsayıları'nı ifade etmektedir.

Modelimiz değişkenlerimizle beraber aşağıdaki gibi kurgulanmıştır.

$\mathrm{g}_{\mathrm{it}}=\beta_{0}+\beta_{1} \mathrm{fbit}+\beta_{2} \mathrm{bds}_{\mathrm{it}}+\beta_{3} \mathrm{kalo}_{\mathrm{it}}+\beta_{4} \operatorname{lnnk}_{\mathrm{it}}+\beta_{5} \mathrm{bh}_{\mathrm{it}}+\beta_{6} \operatorname{lnta}_{\mathrm{it}}+\beta_{7} \mathrm{ncsta}_{\mathrm{it}}+\beta_{8} \mathrm{dvkvk_{ \text {it } }}+\beta_{9} \mathrm{ppdd}_{\mathrm{it}}+\mathrm{u}_{\mathrm{it}}$

\section{Bulgular ve Sonuçlar}

Modelimiz Stat 14.1 programında iki kategorili bağımlı değişken ile farklı tür ve sayıda kategorilere sahip dokuz bağımsız değişken basit lojistik analizine tabi tutulmuştur.

Tablo 4: Basit Lojistik Analiz Yöntemi Sonuçları

Bağımlı Değişken : (g) olumlu görüş "1" olumsuz görüş " 0 "

Toplam Gözlem Sayısı: 320 adet

\begin{tabular}{l|l|l}
\hline Değişkenler & Olasılık Oranı & Standart Sapma \\
\hline Dfb & $\mathbf{4 . 1 5 0 1 7 7 ( 2 . 1 7 ) ^ { * * }}$ & $\mathbf{2 . 7 2 6 3 2 3}$ \\
\hline Bds & $0.4050197(-0.60)$ & 0.7088141 \\
\hline kalo & $\mathbf{1 4 6 6 6 8 4 ( 4 . 0 1 ) ^ { * }}$ & $\mathbf{4 5 2 1 4 8 . 1}$ \\
\hline $\operatorname{lnnk}$ & $0.2914384(1.10)$ & 1.28345 \\
\hline Bh & $\mathbf{0 . 1 3 1 9 0 2 3 ( - 2 . 1 7 ) *}$ & $\mathbf{0 . 6 3 9 3 3 4 7}$ \\
\hline Lnta & $0.14765(3.45)$ & 0.78654 \\
\hline ncsta & $\mathbf{4 9 1 2 . 5 7 ( 2 . 4 0 ) ^ { * }}$ & $\mathbf{1 5 9 7 . 1 1 9}$ \\
\hline dvkvk & $0.1213784(0.295)$ & 0.8629735 \\
\hline ppdd & $0.3717149(0.910)$ & 1.04115 \\
\hline Wald chi2(8) & 62.38 & \\
\hline
\end{tabular}

Turkish Studies - Economy, 15(2) 
BDS-700 Finansal Raporlara İlişkin Görüş Oluşturma ve Raporlama Standardının BİST-50... 793

\begin{tabular}{l|l|l}
\hline Log likelihood & -49.417762 & \\
\hline Goodness-of-fit test & 0.9460 & \\
\hline Hosmer-Lemeshow chi2(8) & 0.3242 & \\
\hline
\end{tabular}

$* 0.01, * * 0.05, * * * 0.10$ anlamlılık düzeyleri, $\mathrm{dfb}=$ Denetim Firma Büyüklüğ̈̈; bds= Bağımsız Denetim Standartları; kalo= Firma Borç Oranı; lnnk= net kârın doğal logaritması; bh=büyüme hızı lnta=firma büyüklüğünün doğal logaritması; ncsta ve dvkvk= likidite oranı; ppdd=piyasa değeri/defter değeri

Modelin bütünüyle istatistiksel olarak anlamlı olup olmadığını saptamak için sonucu incelediğinde, istatistik değerinin anlamlılık düzeyini gösteren olasılık değerinin 0.000 olduğu görülmüştür. Buna göre aşağıdaki sonuçlar tespit edilmiştir:

- Denetim firma büyüklüğü (dfb) değişkeni katsayı değeri 4.150177 ve olasılık değerinin 2.17 olarak belirlenmiştir. Bu sonuca göre $\% 5$ anlamlılık düzeyinde bakıldığında denetim firma büyüklüğü ile bağımsız denetim rapor görüşü arasında istatistiksel açıdan anlamlı ve pozitif bir ilişki bulunmaktadır.

- Denetim bağımsız standartlarının kullanılması (dbs) değişkeni katsayı değeri 0.4050197 ve olasılık değerinin -0.60 olarak belirlenmiştir. Bu sonuca göre $\% 1, \% 5$ ve \% 10 anlamlılık düzeyinde bakıldığında denetim bağımsız standartlarının kullanılması ile bağımsız denetim rapor görüşü arasında istatistiksel açıdan anlamlı ve pozitif bir ilişki bulunmamaktadır.

- Firmanın borçlanma oranı (kaldo) değişkeni katsayı değeri 1466684 ve olasılık değerinin 4.01 olarak belirlenmiştir. $\mathrm{Bu}$ sonuca göre $\% 1$ anlamlılık düzeyinde bakıldığında firmanın borçlanma oranı ile bağımsız denetim rapor görüşü arasında arasında istatistiksel açıdan anlamlı ve pozitif bir ilişki bulunmaktadır.

- Firmaların net kârı (lnnk) değişkeni katsayı değeri 0.2914384 ve olasılık değerinin 1.10 olarak belirlenmiştir. $\mathrm{Bu}$ sonuca göre $\% 1, \% 5$ ve $\% 10$ anlamlılık düzeyinde bakıldığında firmaların net kârı ile bağımsız denetim rapor görüşü arasında arasında istatistiksel açıdan anlamlı ve pozitif bir ilişki bulunmamaktadır.

- Firmanın büyüme hızı (bh) değişkeni katsayı değeri 0.1319023 ve olasılık değerinin -2.17 olarak belirlenmiştir. Bu sonuca göre \%1 anlamlılık düzeyinde bakıldığında firmanın büyüme hızı ile bağımsız denetim rapor görüşü arasında arasında anlamlı ve pozitif bir ilişki bulunmaktadır.

- Firmanın büyüklüğü (lnta) değişkeni katsayı değeri 0.14765 ve olasılık değerinin 3.45 olarak belirlenmiştir. Bu sonuca göre $\% 1 \% 5$ ve $\% 10$ anlamlılık düzeyinde bakıldığında firmaların büyüklüğü ile bağımsız denetim rapor görüşü arasında arasında istatistiksel açıdan anlamlı ve pozitif bir ilişki bulunmamaktadır.

- Firmanın net çalışma sermayesi/toplam aktif (ncsta) değişkeni katsayı değeri 4912.57 ve olasılık değerinin 2.40 olarak belirlenmiştir. Bu sonuca göre \%1 anlamlılık düzeyinde bakıldığında firmanın net çalışma sermayesi/toplam aktif ile bağımsız denetim rapor görüşü arasında istatistiksel açıdan arasında anlamlı ve pozitif bir ilişki bulunmaktadır.

- Dönen varlık/Kısa vadeli yabancı kaynak (dvkvk) değişkeni katsayı değeri 0.1213784 ve olasılık değerinin 0.295 olarak belirlenmiştir. Bu sonuca göre \%1, \%5 ve \% 10 anlamlılık düzeyinde bakıldığında Dönen varlık/Kısa vadeli yabancı kaynak ile bağımsız denetim rapor görüşü arasında istatistiksel açıdan anlamlı ve pozitif bir ilişki bulunmamaktadır.

- Piyasa değeri/defter değeri (ppdd) değişkeni katsayı değeri 0.3717149 ve olasılık değerinin 0.910 olarak belirlenmiştir. Bu sonuca göre \%1, \%5 ve \% 10 anlamlılık düzeyinde bakıldığında pp/dd ile bağımsız denetim rapor görüşü arasında istatistiksel açıdan anlamlı ve pozitif bir ilişki bulunmamaktadır. 
Modelimizin kabul edilip edilmeyeceğine ilişkin uyum iyiliği testi yapmak gerekmektedir. Googness-of-fit test (uyum iyiliği) testlerinden olan Hosmer-Lemeshow testi literatürde yaygın olarak kullanılan testler arasindadır.

Googness-of-fit testlerinden olan Hosmer-Lemeshow testi; modelin bağımlı değişkeni nasıl açıkladığını tespit etmektedir. Modelin uyum iyiliğine baktığımızda 0.9460 oranında görülmektedir. Uyum iyiliği ölçüsü olarak en en çok uygulanan test Hosmer-Lemeshow test istatistiğidir. Küçük örneklemler ile çalışıldığında güçlü bir testtir. Bu teste göre prob(p) değeri 0.05 den büyük olması ile modelin uyumunun olduğu, sonucun " 0 " değerine yaklaşması ile de modelin uygun olmadığını göstermektedir. Modelimize göre ise Hosmer-Lemeshow test istatistik sonucunun 0.32 çıkması modelin anlamlı olduğunu göstermektedir (Hosmer ve Lemeshow, 2000:156). Modelin uyum iyiliği testi yapıldıktan sonra hipotezlerin sonuçları da Tablo 5 de gösterilmiştir.

Tablo 5: Hipotez Sonuçları

\begin{tabular}{|c|c|}
\hline $\begin{array}{l}\text { Hipotez 1: Denetim firma büyüklüğü ile bağımsız denetim raporlarının görüşü } \\
\text { arasında istatistiksel açıdan anlamlı bir ilişki vardır. }\end{array}$ & Kabul Edildi \\
\hline $\begin{array}{l}\text { Hipotez 2: Bağımsız Denetim Standartları-700 ile bağımsız denetim raporlarının görüşü } \\
\text { arasında istatistiksel açıdan anlamlı bir ilişki vardır. }\end{array}$ & Red Edildi \\
\hline $\begin{array}{l}\text { Hipotez 3: Firma Borç Oranı ile bağımsız denetim raporlarının görüşü arasında } \\
\text { istatistiksel açıdan anlamlı bir ilişki vardır. }\end{array}$ & Kabul Edildi \\
\hline $\begin{array}{l}\text { Hipotez 4: Net kâr ile bağımsız denetim raporlarının görüşü arasında istatistiksel açıdan } \\
\text { anlamlı bir ilişki vardır. }\end{array}$ & Red Edildi \\
\hline $\begin{array}{l}\text { Hipotez 5: Büyüme hızı ile bağımsız denetim raporlarının görüşü arasında } \\
\text { istatistiksel açıdan anlamlı bir ilişki vardır. }\end{array}$ & Kabul Edildi \\
\hline $\begin{array}{l}\text { Hipotez 6: Denetlenen firma büyüklüğü ile bağımsız denetim raporlarının görüşü arasında } \\
\text { istatistiksel açıdan anlamlı bir ilişki vardır. }\end{array}$ & Red Edildi \\
\hline $\begin{array}{l}\text { Hipotez 7: Dönen varlıklar/ Kısa vadeli borçlar (dvkvk) ile bağımsız denetim raporlarının } \\
\text { görüşü arasında istatistiksel açıdan anlamlı bir ilişki vardır. }\end{array}$ & Red Edildi \\
\hline $\begin{array}{l}\text { Hipotez 8: Net işletme sermayesi/Toplam varlıklar (ncsta) ile bağımsız denetim } \\
\text { raporlarının görüşü arasında istatistiksel açıdan anlamlı bir ilişki vardır. }\end{array}$ & Kabul Edildi \\
\hline $\begin{array}{l}\text { Hipotez 9: Piyasa Değeri/Defter değeri ile bağımsız denetim raporlarının görüşü arasında } \\
\text { istatistiksel açıdan anlamlı bir ilişki vardır. }\end{array}$ & Red Edildi \\
\hline
\end{tabular}

Tablo 6: Anlamlı Çıkan Değişkenlerin Marjinal Etkileri

\begin{tabular}{l|l|l|l|l}
\hline Değişkenler & $\mathbf{d y} / \mathbf{d x}$ & Standart hata & $\mathbf{z}$ & $\mathbf{p}$ \\
\hline $\mathbf{d f b}$ & 0.0754586 & 0.0338618 & 2.23 & 0.026 \\
\hline kalo & -0.6904423 & 0.1642131 & 4.20 & 0.000 \\
\hline bh & 0.0237183 & 0.0106253 & -2.23 & 0.026 \\
\hline ncsta & 0.3910892 & 0.1583842 & 2.47 & 0.014 \\
\hline
\end{tabular}

BİST-50 endeksine tabi firmalarda; anlamlı kabul edilen değişkenlerin, marjinal etkilere göre bağımsız denetim raporlarının olumlu olma olasılığı yukarıda gösterilmektedir. Buna göre;

Denetim firma büyüklüğündeki bir birimlik artış, bağımsız denetim raporlarındaki görüşü $\mathbf{0 . 0 7 5 4 5 8 6}$ birim artırmaktadır.

Firmaların borçlanma oranındaki bir birimlik artış, bağımsız denetim raporlarındaki görüşü $\mathbf{- 0 . 6 9 0 4 4 2 3}$ birim azaltmaktadır.

Firmaların büyüme hızındaki bir birimlik artış bağımsız denetim raporlarındaki görüşü $\mathbf{0 . 0 2 3 7 1 8 3}$ birim artırmaktadır. 
Net çalışma sermayesi/Toplam Aktif oranındaki bir birimlik artış bağımsız denetim raporlarındaki görüşü $\mathbf{0 . 3 9 1 0 8 9 2}$ birim artırmaktadır.

\section{Sonuç ve Değerlendirme}

Muhasebe standartları, denetim firmalarına ve denetlenen firmalara uyulması gereken konular ve ilkeler bazında birtakım kurallar getirmektedir. Finansal raporlardaki sunulan bilgilerin net ve açık olması, bilgi riskinin olmaması ya da azalması bilgi kullanıcılarını doğru yönlendirmektedir. Ülkemiz de halka açık firmalar bağımsız denetime tabi olmakta ve bağımsız denetim firmalarının denetleme sürecinde uyulması gereken kurallar, Uluslararası Denetim Standartlarının ülkemizdeki mevzuata uyum sağlayacak şekilde dönüştürülerek 2013 yılından itibaren Kamu Gözetim Muhasebe ve Denetim Standartları Kurumunun yayınlamış olduğu "Türkiye Denetim Standartları" ile düzenlenmiştir. Bağımsız Denetim Standard1-700 Finansal Tablolara İlişkin Görüş Oluşturma Ve Raporlama Standardı da bunlardan biri olarak 01.01.2013 tarihinde ve sonrasında başlayacak hesap dönemlerinin denetiminde uygulanmak üzere 18.03.2014 tarihli ve 28945 sayılı Resmi Gazete'de yayımlanmıştır. Bağımsız denetim raporu ile denetçiler, firmaların finansal raporlarının uygunluğu hakkında görüş oluşturup, finansal raporlarının tüm yönleri ile uygun hazırlanıp hazırlanmadığını tespit ederek, denetim süreci hakkında yeterli kanıtlara dayandırarak görüş bildirmektedir.

$\mathrm{Bu}$ çalışma da bağımsız denetim rapor görüşleri BDS-700 kapsamında incelenerek BİST 50 deki firmaların denetim görüşlerini etkileyebilecek bir takım oranlar ile ilişkiler Basit Lojistik Analiz yöntemi ile tespit edilmeye çalışı1mıştır. Bulunan sonuçlara göre;

Denetim firmalarının dört büyükler arasında olması istatistiksel olarak denetim görüş raporlarını etkilemektedir. Denetim firma büyüklügünndeki bir birimlik artış, bağımsız denetim raporlarındaki görüşü 0.0754586 birim artırmaktadır. Bu sonucu, piyasada bilinen ve saygınlığı yüksek olan bağımsız denetim firmalarının raporlardaki görüşlerinin daha şeffaf, açık ve güven vermesine bağlayabiliriz.

Firma Borç Oranı ile bağımsız denetim raporlarının görüşü arasında istatistiksel olarak anlamlı bir ilişki vardır. Firmaların borçlanma oranındaki bir birimlik artış, bağımsız denetim raporlarındaki görüşü -0.6904423 birim azaltmaktadır. Bu sonuca göre, denetlenen firmaların borçlanma oranı sermayelerine göre artarken, denetim rapor görüşlerini değiş̧irecektir. Bunu da bağımsız denetim firmalarının, denetledikleri firmaların piyasadaki ekonomik durumlarından etkilenmelerine, yanlış bir raporlama sonucunda kredi verenler tarafından verilen kararların krizlere kadar yol açabilme tehlikesine vardığından denetim firmalarının olumsuz karar vermelerinde etken olduğu söylenebilmektedir.

Firmaların büyüme hızı ile bağımsız denetim raporlarının olumlu görüşü arasında istatistiksel olarak anlamlı bir ilişki vardır. Firmaların büyüme hızındaki bir birimlik artış bağımsız denetim raporlarındaki görüşü 0.0237183 birim artırmaktadır. Bu sonucun, bağımsız denetçilerin denetim yaptıkları firmanın büyüyen bir firma olmasının raporlamaların da önemli olduğu, buna göre de büyüme hızı bir önceki yıla göre artış sağlayan firmaların bağımsız denetçiler tarafından görüşlerinin olumlu arttığı sonucuna varılmaktadır. Bağımsız denetim firmaları için denetim yaptıkları firmaların ekonomik durumlarının olumlu bir yol çizmesinin görüşü olumlu bir şekilde değiştireceği söylenebilmektedir.

Net çalışma sermayesi/Toplam Aktif ile bağımsız denetim raporlarının olumlu görüşü arasında istatistiksel olarak anlamlı bir ilişki vardır. Net çalışma sermayesi/Toplam Aktif oranındaki bir birimlik artış bağımsız denetim raporlarındaki görüşü 0.3910892 birim artırmaktadır. Firmaların likidite oranının artması yine firmaların ekonomik gücünü gösterdiğinden bağımsız denetim raporlarını değiştirecektir. 
Bulunan sonuçlara göre, denetimi yapılan firmaların ekonomik durumlarının iyi olması ve piyasa da büyüme hızında olmaları bağımsız denetim firmalarının görüşlerini etkilemektedir. Çalışma BİST-50'de yapılarak çalışmanın kısıtı oluşturulurken, başka örneklemler üzerinde yapılması ve başka değişkenlerinde modele eklenmesi ile çalışma genişletilebilir.

\section{Kaynakça}

Akdoğan, N., Güdü, E.S.,Işık, A., Sevindik İ., Şahin, D. \&Özkan.G. (2018). 2014-2016 y1lları arasında BIST şirketleri ile ilgili denetim görüşleri, Muhasebe ve Denetime Bakış, 54, 1-18.

Akgül, A. \& Çevik, O. (2005), Istatistiksel analiz teknikleri (SPSS'de işletme yönetimi uygulamalart), Emek.

Altaş, S. (2016). Bağımsız denetim sonucunda düzenlenecek görüş yazısının türleri ve şirket yönetimine etkisi, Mali Çözüm Dergisi, 139-152.

Arı, M.(2008). Kurumsal yönetim ve finansal raporlamanın güvenilirliği, Osmangazi Üniversitesi IIBFF Dergisi, Ekim,3(2). 43-68.

Aslanoğlu, S., Cengiz S., Dinç Y. \& Dilsiz M.Ş. (2016). Yaratıcı muhasebe uygulamalarının bağımsız denetim kalitesi üzerine etkisi: BİST'de bir uygulama, Muhasebe ve Finansman Dergisi, 1,1-14.

Aydın,A. ve Çürük, T. (2017). Bağımsız denetçinin finansal tablolara ilişkin görüş oluşturma ve raporlama standardından kaynaklanan yükümlülükleri, Çukurova Üniversitesi Sosyal Bilimler Enstitüsü Dergisi, 26(2), 226-238.

Caramanis, C. \& Spathis, C.(2006). Audit and audit firm characteristics as determinants of audit qualifications: Evidence from the athens stock exchangell, Managerial Auditing Journal, 21 (9), 905-920.

Chen, C. J., Chen, S. \& X. Su. (2001). Profitability regulation, earnings management, and modified audit opinions: Evidence from China auditing, A Journal of Practice \& Theory, $20(2), 9-30$.

DeAngelo, L. E. (1981). Auditor size and audit quality, Journal of Accounting and Economics, 3 (3), 183.199.

Doğan, A.(2018). "Bağımsız denetimde yeni bir yaklaşım: kilit denetim konuları", Muhasebe Bilim Dünyası Dergisi, 20(1); 65-89.

Gönen, S. \& Yıldırım F. (2019). Bağımsız denetimde kanıt ve BiST uygulaması, Manas Sosyal Araştırmalar Dergisi, 8 (Ek Say1 1): 1085-1097.

Güredin, E., (2014), Denetim ve güvence hizmetleri; 14. Bask1, Türkmen Kitabevi.

Habib, A. (2013), Meta-Analysis of the determinants of modified audit opinion decisions, Managerial Auditing Journal, 28 (3), 184-216.

Ireland, J. C. (2003), An empirical investigation of determinants of audit reports in the uk, Journal of Business Finance \& Accounting, 30 (7), 975-1016.

Mat, M. \& Önal S. (2019). Bağımsız denetim raporlarında denetim görüşünü etkileyen faktörlerin belirlenmesi: Borsa İstanbul imalat sanayi sektörü şirketleri üzerine bir uygulama, Muhasebe Bilim Dünyası Dergisi, 21 (3):733-760. 
BDS-700 Finansal Raporlara İlişkin Görüş Oluşturma ve Raporlama Standardının BİST-50... 797

Örerler, E.O. (2005). Finansal değerlendirme açısından finansal tabloların şeffaflığı, Muhasebe ve Denetime Bakış Dergisi. 15: 1-8.

Özcan, A. (2016). Determining factors affecting audit opinion: evidence from Turkey, International Journal of Accounting and Financial Reporting, 6 (2), 45-62.

Özşahin, G. (2000). Bağımsız denetçinin hata ve hilelere ilişsin sorumluluğu', SPK yeterlilik etüdü.

Pickett, K.H.S. \& Pickett,M.J.82005), Auditing for managers, Wiley Editorial.

Sağlam, N.,Yolcu, M. \& Eflatun, O. (2014). Örneklerle UFRS kayıtları, Muhasebe TR Yayınları.

Sekizsu, B. \&Ertaş F.C. (2018). Şirketlerin bağımsız denetim raporlarının analizi: Borsa İstanbul'da bir araştırma, Muhasebe ve Finansman Dergisi, 80, 43-64.

Ural, K., Gürarda, Ş. \&Önemli, M. B. (2015). Lojistik regresyon modeli ile finansal başarısızlık tahminlemesi: Borsa İstanbul'da faaliyet gösteren gida, içki ve tütün şirketlerinde uygulama, Muhasebe ve Finansman Dergisi, 67, 85-100.

Yanık, S. ve Karataş, M. (2017). Denetim raporlarının geleceği: yeni düzenlemeler ve ülke uygulamalar1, Muhasebe ve Finansman Dergisi, 73:1-25.

Yaşar, A. (2015). Olumsuz denetim görüşü ve bağımsız denetçi değişikliği arasındaki ilişki: Borsa İstanbul sanayi şirketleri üzerine bir uygulama, Muhasebe ve Finansman Dergisi, 81-96.

Yaşar, A. (2016). Olumlu Görüş Dışındaki Denetim Görüşlerinin Veri Madenciliği Yöntemleriyle Tahminine İlişkin Karar ve Birliktelik Kuralları, Mali Çözüm Dergisi, 133(Ocak-Şubat), 81-109.

Yaşar, A. (2017). İşletmenin sürekliliğinde ortaya çıkan belirsizliğin bağımsız denetim raporlarındaki denetçi görüşleri açısından incelenmesi: BİST'de işlem gören sınai şirketlerine yönelik bir araştırma, Muhasebe Bilim Dünyası Dergisi, 19 (1): 58-85.

https://kgk.gov.tr/Portalv2Uploads/files/Duyurular/v2/BDS/BDS\%20700(2).pdf, Bağımsız Denetim Standard1- 700, Finansal Tablolara İlişkin Görüş Oluşturma ve Raporlama.

https://www.accafin.com/muhasebe/muhasebe-skandallari/acfe-fraud-raporu-2016, ACFE 2016 Fraud Raporu.

https://www.mevzuat.gov.tr/MevzuatMetin/1.5.6102.pdf, Türk Ticaret Kanunu, 